\title{
Construir la política con imágenes e instituir imágenes de lo político. Caras y Caretas, 1898-1916
}

Buil the politics with images and institute images of the political. Caras y Caretas, 1898-1916

Silvana A. Gómez

Universidad Nacional del Centro de la Provincia de Buenos Aires, Argentina

sagkalle@gmail.com

\section{Resumen:}

En el artículo consideramos el semanario Caras y Caretas en el período 1898 (año de su lanzamiento) hasta 1916 (momento en el que según la revista la iconografía política había cobrado importante protagonismo). Tras una breve presentación de Caras y Caretas, estudiamos los modos con los que el semanario plasmó la incorporación de imágenes en la política. Luego, abordamos caricaturas de portada a partir de un análisis indiciario. Los intensos vínculos entre palabras e imágenes así como la distinción entre la política y lo político recorren este trabajo.

Palabras clave: Política, Argentina, Construcción, Imágenes, Caras y Caretas.

\section{Abstract:}

In the article we consider the weekly Caras y Caretas in the period 1898 (year of its launch) until 1916 (at wich time acoording to the magazine the political iconography was developed). After a brief presentation of Caras y Caretas, we study the weekly review of the incorporation of images in politics. Rhen, we cover cartoons base don a index analysis. The intense links between Word and images as well as the distinction between politics and the politics go through this work.

KeYwords: Politics, Argentina, Construction, Images, Caras y Caretas.

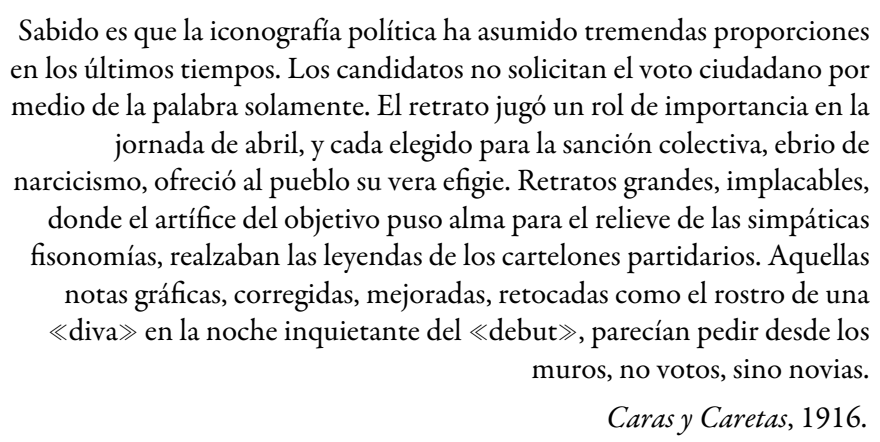

\section{A Modo DE INTRODUCCIÓN.}

Con miradas más o menos entusiastas que viraban en algunos casos a dictámenes sombríos, los contemporáneos de la segunda década del siglo XX encontraron en las publicaciones periódicas espacios donde difundir sus opiniones sobre la realidad política argentina. Heredera de la tradición decimonónica que comenzaba a perfilar los senderos que se recorrerían durante el siglo (Román, 2010a), esa prensa para algunos ya decididamente "moderna” (Saítta, 1998; Román, 2010a y 2016; Caimari, 2015 y Szir, 2016), o que incluye para otros novedades constituidas por reacomodamientos de elementos ya presentes en el siglo XIX ante nuevos desafíos, discusiones y demandas (Bonaudo, 2005; Mauro, Cesaretti, y Uliana, 2005; Man, 2011 y Gómez, 2016b) se componía de publicaciones variadas que se multiplicaban (Román, 2010a y 2010b) en un mercado de bienes culturales socialmente diversificado (Roldán, 2006). En sus páginas se 
plasmaron percepciones que hacían hincapié en las transformaciones del plano institucional (Pereyra, 1958; Ansaldi, 1999 y 2012; Zimmermann, 1995; Gallo y Cortés Conde, 2005 [1995]; De Privitellio, 2006 y 2009 y Tato, 2009) y/o en las permanencias en los modos de practicar la política (Botana, 2012 [1977]; Rock, 1997 [1977], Ansaldi, Pucciarelli y Villaruel, 1995; Devoto y Ferrari, 1994; Botana y Gallo, 1997; Karush, 1999; Alonso, 2000; Ferrari, 2008; Horowitz, 2014; Miguez, 2003 y 2012 y Castro, 2012), en un contexto de profunda condena a determinadas acciones (Persello y de Privitellio, 2009; Gómez, 2016) y de debate intenso: "el de la utopía de un ciudadano consciente que alimentara a una política de principios, el de un pueblo comprometido con la cosa pública" (Bonaudo y Mauro, 2014, p. 120).

Algunas de las publicaciones que surgieron en la década de 1910 apelaron principalmente a elementos textuales. Ejemplo emblemático en ese sentido quizás sea la Revista Argentina de Ciencias Políticas (Roldán, 2006; Leiras, Abal Medina y D'Alessandro, 2005; Ferraro, 2003; Cárdenes, 2014). De carácter científico (Auza, 2008), circulaba junto a diarios, periódicos, magazines y suplementos en una Argentina donde la población seguía creciendo de forma significativa ${ }^{1}$ y el analfabetismo se reducía. ${ }^{2}$

Si desde mediados del siglo XIX "saber leer (...), ser instruido en los secretos de la letra impresa o invocar, por lo menos, algún somero rito de iniciación escolar, fueron objetivos que hicieron su camino propio en la población" (Prieto, 2006 [1988], p. 31), para el período 1880-1900 puede hallarse "una serie de cambios (...) que acompañaron e impulsaron transformaciones en la composición del público, en la sociabilidad y también en las características (...) de las publicaciones periódicas” (Román, 2010a, p. 18). Efectivamente, en este contexto, otras publicaciones que comenzaron a circular en la segunda década del siglo XX se vincularon estrechamente a la imagen, como Plus Ultra, suplemento aparecido en 1916. Pues desde mediados del siglo anterior, la prensa satírica había incorporado imágenes con éxito (Román, 2010b) merced a los adelantos técnicos así como a la avidez por las mismas (Szir, 2016).

Pero fue Caras y Caretas la que desde finales del siglo XIX puso a disposición de un número de personas, hasta entonces desconocido, mensajes que combinaban elementos textuales e imágenes, en tanto ya se había conformado un nicho de lectores-espectadores a los que la revista se dirigió. Por medio de esa combinación posibilitada por nuevas técnicas, siguió reforzando y precisando ese vínculo intenso entre palabra e imagen, que cada lector-espectador eventualmente restablecería y redefiniría.

Es que la ampliación del público lector “(...) supuso una transformación tan global como radical en la cultura letrada” (Pastormerlo, 2014 [2006], p. 1) y mientras se creaban nuevos hábitos de lectura (Sarlo, 1985), Caras y Caretas masificó las funciones que habían tenido las revistas en el siglo XIX (Rojas, 1948). El mercado criollo se mostró receptivo a este tipo de publicación inspirada en los magazines europeos (Rivera, 1985) y/o en la cultura periodística norteamericana (Ludmer, 1999). Se trataba de un amplio público, que demandaba informaciones cercanas y lejanas. Para 1890 las páginas de los periódicos de Buenos Aires se habían colmado de informaciones provenientes de distintas partes del mundo a partir del desarrollo del telégrafo (Caimari, 2015) y crecían en número los que en la época se denominaban indistintamente enviados especiales, corresponsales y reporters viajeros (Servelli, 2014).

Caras y Caretas, en este contexto, respondió a esa avidez como ya lo habían hecho otras publicaciones. La novedad inserta por el semanario, sin embargo, fue crear los más variados mensajes constituidos y ordenados por medio de elementos textuales e icónicos, destinados a un amplio público que no dejaba de expandirse y apreciar el proyecto editorial. Mientras la primera tirada del semanario contó con 7000 ejemplares (Taub, 2008), ya en 1904 se vendían alrededor de 75.000 semanales alcanzando su pico de ventas con un ejemplar especial Centenario en 1910 que superó las 200.000 unidades vendidas (Taub, 2008).

Desde su primer número publicado en 1898 y por más de cuatro décadas, semana tras semana sus páginas intercalaron caricaturas, notas periodísticas con fotografías, relatos ilustrados, reproducciones de cuadros y textos literarios, entre otros. Durante todo ese período, se sostuvo el carácter misceláneo que dotó a Caras y Caretas de su impronta: "Semanario festivo, literario, artístico y de actualidades", según expresaba su subtítulo. A través de un solo ejemplar, se podía acceder a informaciones provenientes de España, Italia, 
Francia, Rusia y Japón, conocer los entretelones de la lucha de los ingleses en el Tíbet o el estado del Museo Nacional en Argentina, las adquisiciones de animales del jardín zoológico de Buenos Aires, los pormenores de la intervención a San Luis, el match internacional de fútbol y las necrológicas al tiempo que ser interpelado por numerosas publicidades. Si el listado anterior surge tomando solo algunas referencias del número 300 del 2 de julio de 1904, vista en conjunto puede afirmarse que Caras y Caretas representó “(...) una suerte de enciclopedia barata, entretenida, fácil de transportar y coleccionable para quienes no solían frecuentar librerías ni bibliotecas" (Rogers, 2008, p. 17).

Durante toda su existencia, además, acrecentó el número de hojas en cada entrega. Aunque la gacetilla de lanzamiento anunció que esperaba contar con unas 20 páginas semanales, para 1902 contaba con 68, en 1906 con unas 90 y en la segunda década del siglo con unas 130 en promedio. El incremento en el número de páginas se tradujo en una diversificación de las secciones: a "Sports", "Actualidades", "Sinfonía”, "Caricaturas contemporáneas", "Menudencias", "Correo sin estampilla”, "Actualidad internacional”, "Inventos útiles", "Páginas infantiles" y reproducciones de textos varios, se incorporaron entre otras "Teatros", "Para la familia" y los "Folletines de Caras y Caretas". Esta proliferación de temas estaba sin embargo meticulosamente dispuesta en las tres partes que cada ejemplar presentaba (Rogers, 2008). Tras la portada siempre a color y en su mayoría compuesta por una caricatura, un primer fragmento que constituía el $30 \%$ del ejemplar aparecía dividido en secciones donde diversas notas se intercalaban con publicidades. Luego de una carátula interna, una segunda parte con notas y numerosos elementos visuales (especialmente fotografías) sin ningún tipo de anuncio publicitario, componía el $40 \%$ del número. Finalmente, y tras una publicidad de hoja completa, aparecía un conjunto de páginas donde se intercalaban notas y publicidades y en el cual realzaba la contratapa a color con un anuncio comercial de, por ejemplo, Iperbiotina Malesci o Fernet Branca. La publicidad fue fundamental en un proyecto editorial concebido desde sus orígenes como una empresa que debía asegurar la profesionalización de periodistas, escritores y dibujantes (Rogers, 2008). Los dividendos derivados de la prolífera incorporación de anuncios a las páginas, al mismo tiempo, aseguraron un bajo costo que hizo al semanario accesible a sectores medios y bajos (Moraña, 2008): en 1902 un ejemplar de la revista seguía costando lo mismo que en 1898, 20 centavos en Buenos Aires y 25 en el interior, el equivalente al precio de un kilo de pan. ${ }^{3}$ En esas publicidades, como en la revista en general, textos e imágenes se combinaban.

Sin embargo, esta proliferación de mensajes compuestos por palabra y gráfica no era una característica exclusiva de las publicaciones periódicas sino que alcanzaba el terreno político. Entre finales del siglo XIX y comienzos del XX, un número cada vez mayor de personas participaría activamente, por ejemplo, en los procesos electorales. En el examen de Caras y Caretas, quienes formaban parte o aspiraban a constituir el sector dirigente encontraron en la combinación de textos y elementos icónicos (como ya lo hacían distintas publicaciones) valiosos recursos para interpelar a lectores-espectadores que eventualmente podrían transformarse en sus votantes. Para la segunda década del siglo XX (y de allí que en esta introducción nos hayamos detenido en ese momento) el semanario dio cuenta de la extensión que había alcanzado la llamada iconografía politica. Su presencia daba lugar a todo tipo de comentarios, como aquel que en 1916 de cara a las elecciones de ese año, encontró en algún candidato un "rostro de una «diva» en la noche inquietante del «debut»" que parecía pedir desde los muros "no votos, sino novias" tal como expresa el fragmento con que se inician estas líneas ("Después de la lucha. Los estoicos” en Caras y Caretas, 29/04/1916).

En este artículo consideramos el período 1898 (momento en el que empieza a circular la revista) hasta 1916 (año en el que, según la revista, podía constatarse el gran desarrollo alcanzado por la iconografía política). Estudiamos primero la ponderación que el semanario hizo de la construcción de la política con imágenes. Para ello, avanzamos en la identificación de fotografías y caricaturas publicadas por la revista que buscaban revelar la propagación de dicha iconografía (a partir de carteles, afiches y pancartas que aludían a diversas fuerzas políticas). Durante el período analizado en este trabajo, encontramos que Caras y Caretas remarcó la progresiva incorporación de imágenes a la actividad proselitista que contrastaba con los elementos únicamente textuales que habían primado a finales del siglo XIX. En la segunda parte de este artículo 
mediante un análisis indiciario, analizamos algunas caricaturas de portada que focalizaron en determinados aspectos del funcionamiento político (como la compra venta de votos, el fraude electoral, las estrategias de los votantes y la ampliación de electorado, entre otras).

Sea por medio de las fotografías o caricaturas que instaron a detener la mirada en la iconografía política o a través de las caricaturas que ridiculizaron específicamente formas de la conocida como politica criolla, buscamos aproximarnos a la institución de imágenes de lo político emprendida por la revista. Es decir, queremos hacer hincapié en la capacidad que tuvo el seminario de introducir, establecer, crear y formular determinadas formas de entender, aproximarse y comprender la realidad. Entendemos que en la combinación realizada por el semanario de imagen y texto presente en distintos mensajes visuales destinados a un público en constante expansión, es posible advertir "la fuerza performativa de la palabra que maldice, conjura o convence, la capacidad de la imagen de hacer presente lo ausente, o las posibilidades de reproducción y conservación sólo otorgadas por lo escrito" (Chartier, 2008, p. 25).

Una tensión conceptual atraviesa todo este trabajo: "la política" y "lo político" en tanto adquieren connotaciones específicas,

Al hablar sustantivamente de lo político, califico de esta manera a una modalidad de existencia de la vida comunitaria y a una forma de la acción colectiva que se diferencia implícitamente del ejercicio de la política. Referirse a lo político y no a la política es hablar de poder y de la ley, del Estado y de la nación, de la igualdad y de la justicia, de la identidad y de la diferencia, de la ciudadanía y de la civilidad, en suma, de todo aquello que constituye a la polis más allá del campo inmediato de la competencia partidaria por el ejercicio del poder, de la acción gubernamental del día a día y de la vida ordinaria de la instituciones (Rosanvallon, 2006, pp. 19-20).

Caras y Caretas al retratar, construir y dotar de sentido por medio de caricaturas y fotografías que aludieron a aspectos formales de la política o a su ejercicio, posibilita adentrarse en la institución de lo político realizada por el semanario, en tanto la revista pretendía instalar ciertas visiones y percepciones acerca del savoir faire político epocal. En esta línea, se presentan las reflexiones al final de estas páginas.

\section{Construir LA POLÍTiCA CON IMÁGENES}

A lo largo del período analizado, la revista Caras y Caretas subrayó una novedosa construcción de la política. Según el semanario, el proselitismo emprendido por distintas agrupaciones y/o partidos ${ }^{4}$ incorporó paulatinamente imágenes que contrastaban con los carteles ${ }^{5}$ y pancartas meramente textuales de finales del siglo XIX.

La realidad a la que Caras y Caretas aludió encontró entonces un elemento de impronta en las manifestaciones iconográficas referidas a la política. Analizar estas imágenes (las que estaban presentes en esos carteles y pancartas, que quedaron a su vez plasmadas en otras imágenes como las fotografías y caricaturas con las que la revista dio cuenta de esa realidad) implica tener en cuenta que la imagen "escolta su significado (lo permanente) por medio de opciones significantes variadas, múltiples, distintas” (Gubern, 1996, p. 28) y que no debería interpretarse como reflejo sino como una sofisticada forma de construcción de realidad (Pérez Vejo, 2005). Este tipo de fuente constituye una “(...) entidad autónoma con una intensidad propia, creadora de realidades, cuya mera enunciación muestra su amplitud y trascendencia” (Rojas Mix, 2006, p. 21), pues la imagen condensa realidades sociales.

Aunque durante el siglo XX algunos investigadores habían llamado la atención al respecto (Huizinga, 1905 en Burke (2005 [2001]); Ariés, 1980 y Vovelle, 1979), solo en los últimos años comenzó una reflexión acerca de las potencialidades de estas fuentes, sintetizada en la obra de Burke (2005 [2001]). Resultan especialmente atractivas las investigaciones de Ginzburg (1984 [1981] y 2014) y Burucúa (2006) en tanto la metodología propuesta en sus trabajos permite considerar los vínculos entre palabra y texto. Esos vínculos se volvieron particularmente intensos desde el siglo XX pues, a partir de ese momento, no asistimos a un uso extenso de 
la imagen sino a una comunicación mixta donde la imagen no queda desprovista de palabra (Barthes, 2001 [1993]). Considerando esa comunicación mixta característica de este período, estudiamos en este apartado las múltiples referencias hechas por Caras y Caretas a los carteles diseminados en las paredes, muros y en el exterior de clubes políticos por un lado y las pancartas sostenidas por distintos manifestantes, por otro.

Entre finales del siglo XIX y comienzos del XX, Caras y Caretas manifestó la propagación de carteles y afiches por medio de fotografías y caricaturas, como en 1907 cuando definió al Leopoldo Metlicovitz (1868-1944) como un "notable cartelista" que estando en Buenos Aires había "producido ya entre nosotros algunos «affiches» que, fijados en las calles del municipio, han llamado la atención del público" ("Retratos de actualidad” en Caras y Caretas, 31/08/1907). El valor artístico de la obra de Metlicovitz lo había llevado a convertirse en el ganador de un concurso internacional lanzado por el semanario en ocasión del número especial centenario aparecido el 21 de mayo de 1910, siendo su dibujo el que constituyó aquella icónica portada.

En lo que refiere específicamente a carteles políticos, la revista presentó los muros colmados de ellos en varias portadas (primer encuentro entre cada lector-espectador con la revista). (Véase Figura 1)

FIGURA 1

Mayol “Contrapunto de carteles. ¿Quién tapa a quién?”
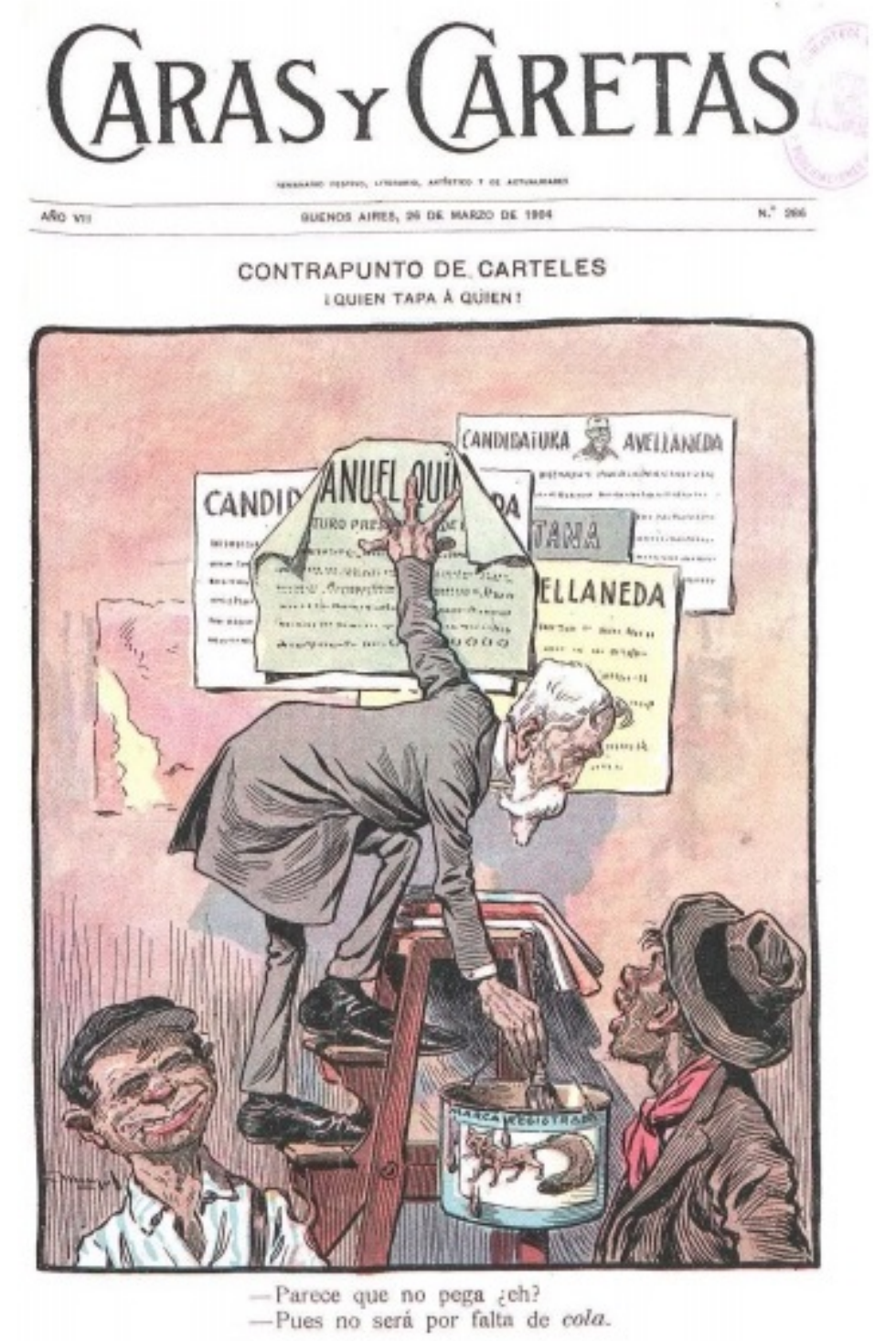

["Caricatura de portada] en semanario Caras y Caretas, 26 de marzo de 1904, n. ${ }^{\circ} 286$, año VIII 
Según el semanario, su propagación era tal en los inicios del siglo, que se colocaban unos encima de los otros. Considerando el ejemplo propuesto en la figura 1, encontramos que en su mayoría estuvieron compuestos de textos y solamente en uno es posible advertir una pequeña imagen de un candidato.

Caras y Caretas presenta también una proliferación de pancartas sostenidas por simpatizantes en manifestaciones de distinto color político, como puede apreciarse en algunas caricaturas de tapa. (Véase Figura 2)

\section{FIGURA 2}

Progresión de portadas de Caras y Caretas que hacen referencia a manifestaciones (1901-1916).
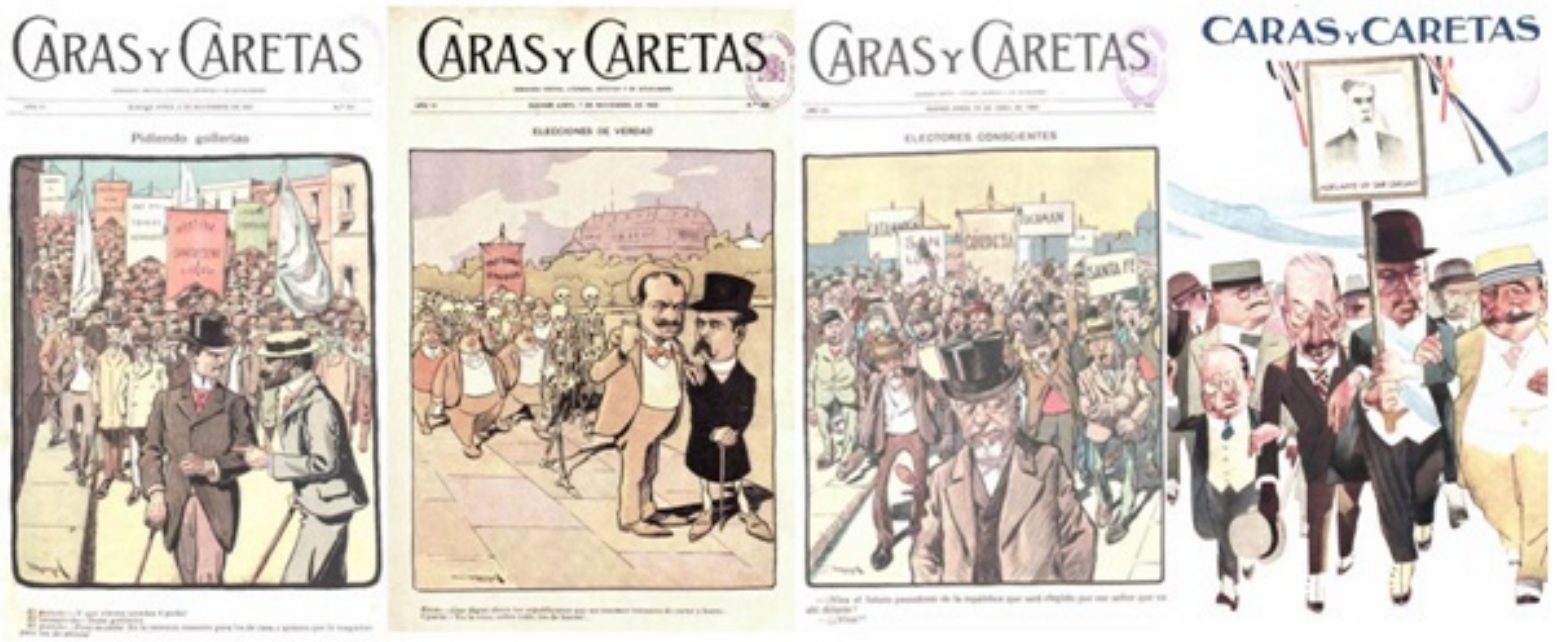

Fuente: [Elaboración propia]

Se trata de una progresión de elaboración propia que muestra cuatro caricaturas de portada en orden cronológico. ${ }^{6}$ Solo en la última, publicada en tapa en octubre de 1916 y que constituye un collage, se halla una imagen dentro de una pancarta. Ese montaje no puede ser explicado por una disposición técnica. La combinación de dibujo y fotografía ya se había hecho en la revista en una caricatura de portada de 1899 y además en décadas anteriores este mismo procedimiento se había implementado en El Mosquito (Román, 2016; Cuarterolo, 2017). La inclusión de imágenes en las pancartas caricaturizadas entonces, parece responder más bien a un aspecto que el semanario intentó remarcar: la segunda década del siglo XX, según Caras y Caretas, tenía entre sus características la inclusión de imágenes en el proselitismo.

Desde 1912 Caras y Caretas buscó poner de relieve que textos e imágenes interpelaban a los electores, aunque en paralelo se difundieran pancartas y carteles meramente textuales. En ese sentido, varias fotografías publicadas en el semanario en el contexto de las elecciones de aquel año muestran una proliferación de personas sosteniendo pancartas que incluyen exclusivamente palabras. (Véase Figura 3). 
FIGURA 3

Personas sosteniendo pancartas.
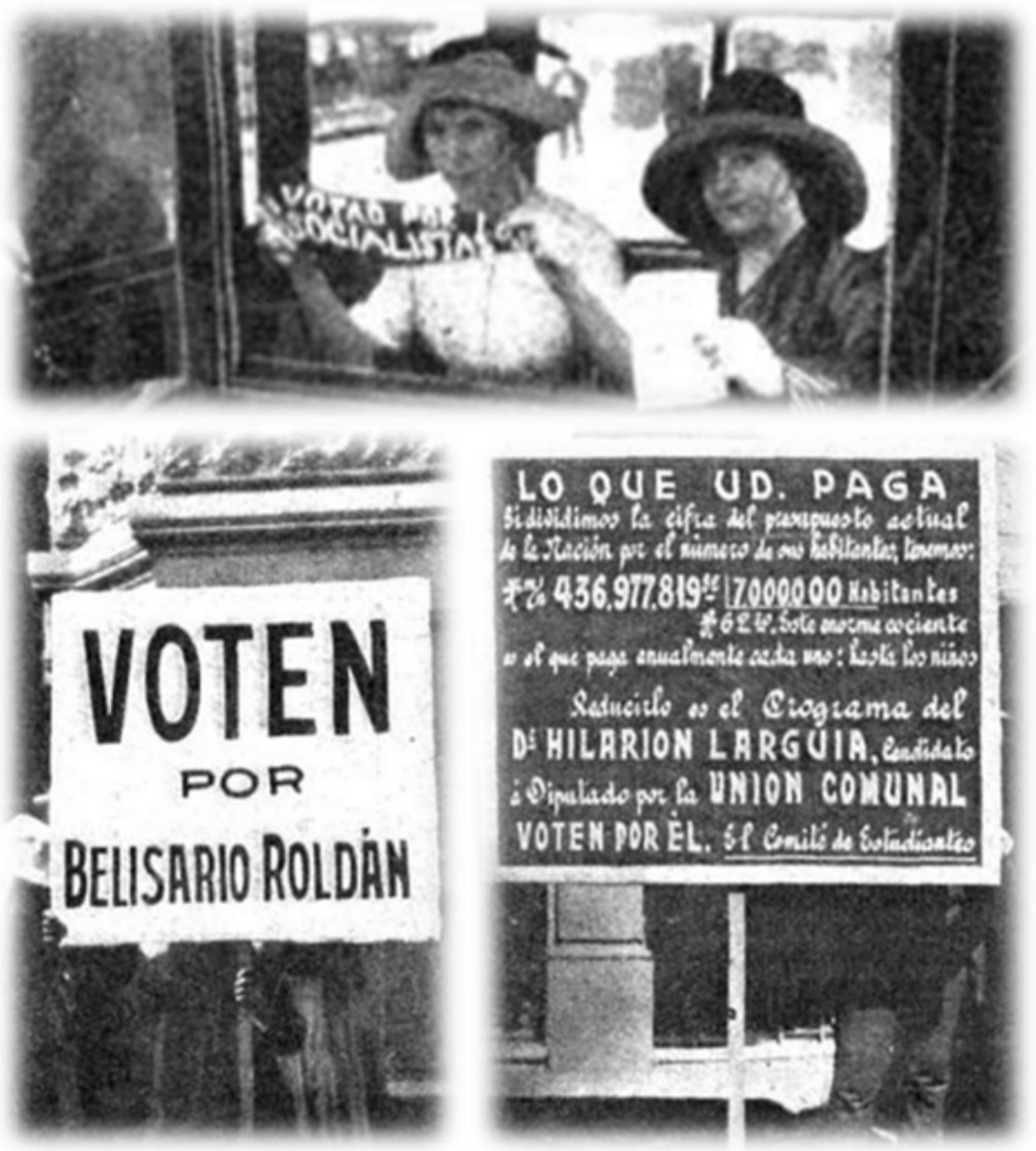

Fotografías publicadas en Caras y Caretas, 1912. (Esquema de elaboración propia).

También existían carteles compuestos por textos únicamente, como aquel colocado en el Club Carlos Pellegrini (dirigido por Cayetano Ganghi) donde podían leerse los pormenores de la violación a la ley electoral: "Con cuatro meses de arresto los que vendan votos, con seis meses de arresto los que los compren. / En el Club "Carlos Pellegrini” /NO SE COMPRAN VOTOS. /Cayetano Gangui” (sic) ("La reclame electoral” en Caras y Caretas, 13/04/1912). (Véase Figura 4). 
FIGURA 4

Cartel colocado en el Club Carlos Pellegrini.

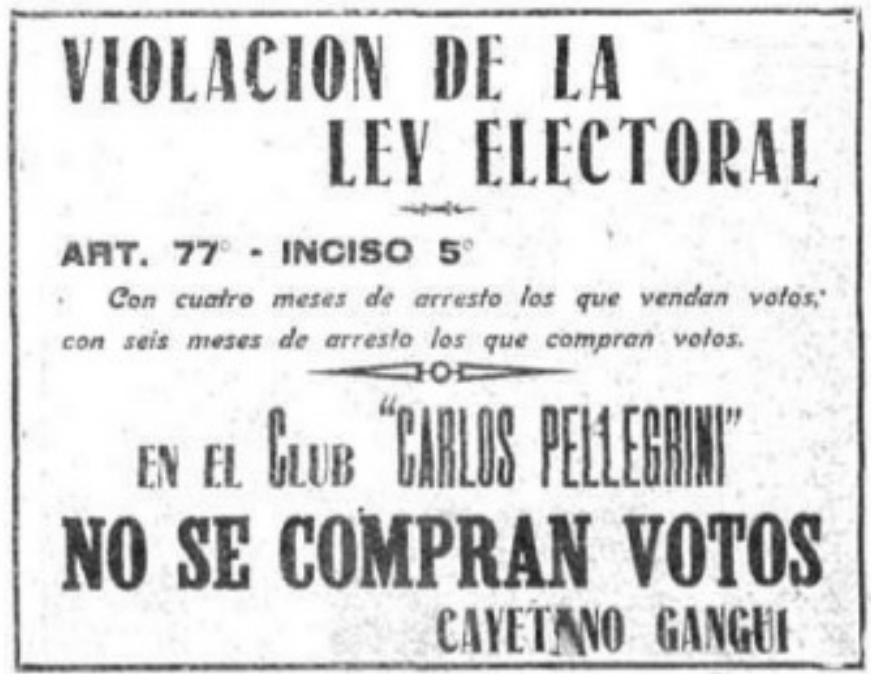

Fotografía publicada en Caras y Caretas, 1912.

Sin embargo, el elemento novedoso que el semanario remarcó de la campaña electoral de 1912 fue la incorporación de imágenes, pues en paralelo al desarrollo de carteles y pancartas textuales, aparecieron muchos que combinaban palabras e imágenes. Caras y Caretas publicó varias fotografías en las que puede observarse una gran cantidad de carteles con esas características dispuestas en los muros. (Véase Figura 5).

FIGURA 5

Carteles que combinaban textos e imágenes. Campaña electoral de 1912.

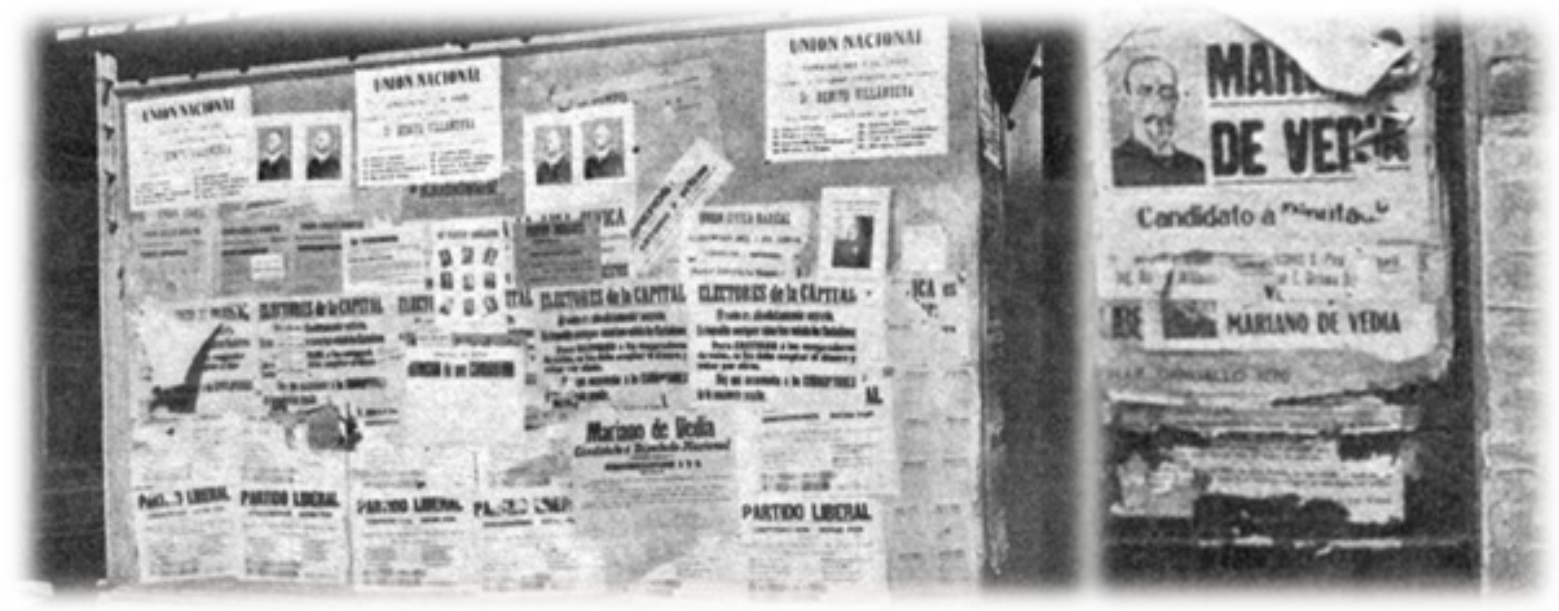

Fotografías publicadas en Caras y Caretas, 1912. (Esquema de elaboración propia).

En la transición de una política de notables a otra que se democratizaba, incluyendo a un número cada vez mayor de personas, la revista señaló que los potenciales electores eran interpelados a partir de breves textos, con un mismo mensaje, "Vote por...", y excepcionalmente, con propuestas de mayor extensión. En general y en función de las fotografías y caricaturas publicadas en el semanario, una tipografía más grande resaltó el nombre del candidato y/o el nombre de la fuerza política. Hacia 1912 entonces, y aunque es posible hallar con anterioridad a la campaña de aquel año pequeñas imágenes, encontramos palabras vinculadas profundamente a elementos icónicos. En la cobertura de Caras y Caretas, se trata de la primera contienda electoral que incluyó 
sistemáticamente mensajes compuestos por palabras e imágenes. Precisamente, en el momento en que la obligatoriedad del voto fue sancionada (más allá de la universalidad masculina, el secreto del sufragio y la representación de las minorías asegurada por la ley n. ${ }^{0} 8871$ ). Esta incorporación de imágenes tendría como resultado el desarrollo de la iconografía política que, para 1916, tendría una presencia notoria según afirmó la revista.

Que la masividad en las urnas (aunque con las limitaciones de género y étnicas y la presencia efectiva de electores en los comicios) conllevara un enlace de palabras e imágenes en dicha iconografía, requiere de un estudio de mayor alcance que aborde otras fuentes además del semanario. Lo que puede afirmarse es que en el período analizado hay una imagen construida por el semanario acerca del uso que la política realizaba de la imagen. En las páginas de Caras y Caretas se presentaron fotografías que retrataron una iconografía compuesta de imágenes de candidatos con sus nombres, la que eventualmente interpelaría a votantes de las distintas fuerzas políticas. Mientras con anterioridad se habían destacado los nombres de los candidatos o las denominaciones de las distintas fuerzas, para Caras y Caretas la actividad proselitista encontró en su horizonte de prácticas y estrategias, la interpelación a lectores-espectadores por medio de la combinación de palabras e imágenes. En un contexto de inusitada imprevisibilidad en tanto la nueva ley electoral trastocó parte de la praxis, puede considerarse que la construcción de la política apeló a nuevos recursos para alcanzar resultados ya conocidos: enfatizó en las personas (dando a conocer rostros ajenos al cotidiano de los potenciales votantes) por sobre las estructuras políticas que los amparaban en la contienda electoral, buscando hacer trascender en sus expresiones iconográficas públicas a determinados actores. En suma, y considerando las fotografías y caricaturas abordadas, pareció apelar al personalismo. Aunque ello podría coincidir con un fragmento de la realidad (pocas informaciones se disponen en el semanario acerca de los muros de qué espacios fueron fotografiados, las caricaturas son en general imprecisas en ese sentido), más bien se trata de la formulación propia de la revista que, optando por publicar unas fotografías y descartando otras, incorporando unas caricaturas por sobre otros mensajes visuales pretendió señalar $-\mathrm{y}$ al hacerlo constituyó- parte de la realidad sociopolítica de aquellos años.

Estamos entonces una vez más revisitando a Caras y Caretas, considerando específicamente en sus páginas su mirada y aporte al entendimiento del mundo político. Pues aunque las publicaciones resultan de asombrosa riqueza, los trabajos sobre prensa en general han sido más habituales en otros países que en el nuestro (Roldán, 2006). Ante el supuesto que "el fenómeno del surgimiento de las revistas recorre las últimas décadas del siglo XIX, pero adquiere una marcada influencia en el mundo editorial latinoamericano y fundamentalmente argentino a partir de la primera posguerra" (Fernández, 2010, p. 15), solo en los últimos años se ha comenzado a ahondar en diversos tipos de publicaciones periódicas con un particular acento en las aparecidas en este período (Sidicaro, 1993; Saítta, 1998; Girbal-Blacha y Quattrochi-Wilson, 1999; Eujanián, 1999; Roldán, 2006; Fernández, 2010 y Fernández y Navarro, 2011). Además de las investigaciones ya mencionadas en las páginas anteriores, variados estudios han hecho referencia al contenido textual y visual de la revista Caras y Caretas (Fara, 2012; Gamarnik, 2018; Cardona Laites, 2015; Cuarterolo, 2017 y Tell, 2017 entre otros). Considerada como documento, su abordaje ha permitido percibir el rol de la propaganda y la imagen de la mujer (Moraña, 2008), su aporte en la conformación de la otredad (Taub, 2008) y en la formación de imágenes socialmente imaginadas acerca de la trama política (Gómez, 2013 y 2015). Empero, entendemos que es necesario insistir en el papel desempeñado por el semanario en tanto facilitador para el encuentro entre un número cada vez mayor de personas (lectores-espectadores) y la política (Gómez, 2017). En otras palabras: al tiempo que el semanario entendió, percibió y ponderó la construcción de la política con imágenes (difundiendo desde sus páginas estas novedades), realizó una contribución acerca de cómo funcionaba en la práctica dicha política. Por las características de la publicación y su alcance, el aporte del semanario estuvo destinado a un amplio público que encontraba en esas páginas combinaciones de palabras e imágenes en mensajes visuales intencionados. Por medio de esos mensajes, el gran número de lectores-espectadores 
(potenciales electores) conocían los entretelones políticos de una forma específica: los formulados por la revista. En ese sentido, proponemos que Caras y Caretas instituyó imágenes de lo político.

\section{INSTITUIR IMÁGENES DE LO POLÍ́TICO.}

Además de dar cuenta del desarrollo de la iconografía (por medio de fotografías y caricaturas que ponía de relieve la introducción de imágenes que contrastaban con los mensajes meramente textuales de finales del siglo XIX), Caras y Caretas señaló algunas formas consideradas, dentro del semanario, como modos concretos de desarrollar la política. Se trató de ridiculizaciones y exageraciones presentadas en portada: nos referimos a las caricaturas de tapa. Esas caricaturas se componían de un dibujo que apelaba a resaltar algunos elementos (utilizando con ese fin la palabra en muchos casos) o directamente apelando a diálogos o estrofas que terminaban de orientar sentidos (previstos desde el título del mensaje visual).

El estudio de la caricatura política "posibilita descubrir los aspectos más relevantes que interesaban a un conjunto social específico y recuperar la historia desde una perspectiva alterna” (Gantús, 2009, p. 21). Puede considerarse “(...) una estrategia fundamental en la construcción de imaginarios colectivos” (Gantús, 2007, p. 205) ya que a partir de su desarrollo se generan ciertas ideas y se difunden determinadas percepciones mediantes las cuales se incidía sobre la opinión del público.

Es notorio que uno de los tres responsables de Caras y Caretas al momento de su lanzamiento fuera el encargado de realizar este tipo de mensaje visual. Mientras la dirección quedó en manos de José S. Álvarez (Fray Mocho) y la redacción a cargo de Eustaquio Pellicer, la tríada se completaba con Manuel Mayol, presentado en tapa como dibujante y, en la práctica, uno de los más hábiles y prolíferos caricaturistas del semanario, como lo demuestra el hecho de que muchas de las caricaturas mencionadas en el apartado anterior sean de su autoría. Incluso la revista a través de imágenes y de textos dio cuenta de la importancia de las caricaturas (Gómez, 2015 y 2016a).

En el período aquí analizado, la mayoría de las tapas estuvieron compuestas por caricaturas (y las excepciones se registran en muy pocas ocasiones constituidas por números especiales o almanaques que aparecían con ilustraciones). Esas caricaturas, al mismo tiempo, hacen referencia en casi todas las oportunidades a aspectos específicos del funcionamiento político tales como la constitución de campañas electorales, el desarrollo de los comicios o los accionares de mediadores y electores, entre otros. Se registra asimismo una importante cantidad de portadas que focalizan su atención en la provincia de Buenos Aires. No se trata de un procedimiento atípico en la época. Aunque Rodolfo Rivarola, fundador y director por varios años de la ya mencionada Revista Argentina de Ciencias Políticas, expresó que "no hay tal vez publicación periódica alguna en que se haya tratado el estado político de Buenos Aires mayor número de veces, y en que, dentro de los propios materiales, otro asunto haya tenido mayores preferencias" (Rivarola en Revista Argentina de Ciencias Politicas, 1917, p. 118), lo cierto es que Carasy Caretas, especialmente en sus portadas, ${ }^{7}$ realizaba también una suerte de sinécdoque por la cual la consideración de la realidad bonaerense permitía un examen de la política argentina.

En un juego especular entre instancias macro y micro analíticas entonces, la tensión entre nación y provincia resultaba altamente atractiva para muchos contemporáneos en tanto permitía revisitar aspectos sociopolíticos en función de examinar las condiciones específicas de la provincia de Buenos Aires. Allí, los “conservadores bonaerenses" (Walter, 1987; Mustapic, 1987; Barba, 2004; Béjar, 2005), una vez realizadas las modificaciones electorales a nivel nacional en 1912, intentaron con ímpetu sostener su preeminencia mediante un conjunto de leyes provinciales establecidas en 1913 y 1914 que contenían intersticios normativos y permitían la actuación de líderes locales: particularmente, el municipio empadronador y corregidor como reaseguro que posibilitaba la perpetuación en el poder del mismo grupo dirigente (Melón, 1994; Paredes, 1996; Ferrari, 2009 y Gómez, 2016). 
Considerando este contexto, examinamos dos caricaturas de portada del semanario publicadas respectivamente en 1903 y 1916, las que entendemos como representativas para el abordaje del examen de la democratización de inicios del siglo XX, realizado por la revista. Realizamos un análisis indiciario, considerando que una indagación de esas características no debiera convertirse "en un pretexto para una serie de asociaciones libres que generalmente se basan en una presunta interpretación de símbolos" (Ginzburg, 1984 [1981], p. 20). En ese sentido, "el camino de salida no es la eliminación, más o menos tácita, de la exigencia del cotejo documental sino la elaboración de instrumentos de cotejo adecuados" (Ginzburg, 1984 [1981], p. 20) a partir de una interpretación iconográfica reubicada en su contexto por medio del estudio de otras fuentes (entre ellas las textuales), metodología implementada también por Burucúa (2006).

II a.

En plena jornada electoral bonaerense de 1903, un muñidor confirma si un elector ha votado por el candidato indicado. El votante lo hizo, veintitrés veces. La situación es construida en la caricatura "Las elecciones en la provincia”, publicada en tapa el 25 de abril de 1903 (Véase Figura 6).

FIGURA 6

Mayol "Las elecciones en la provincia"

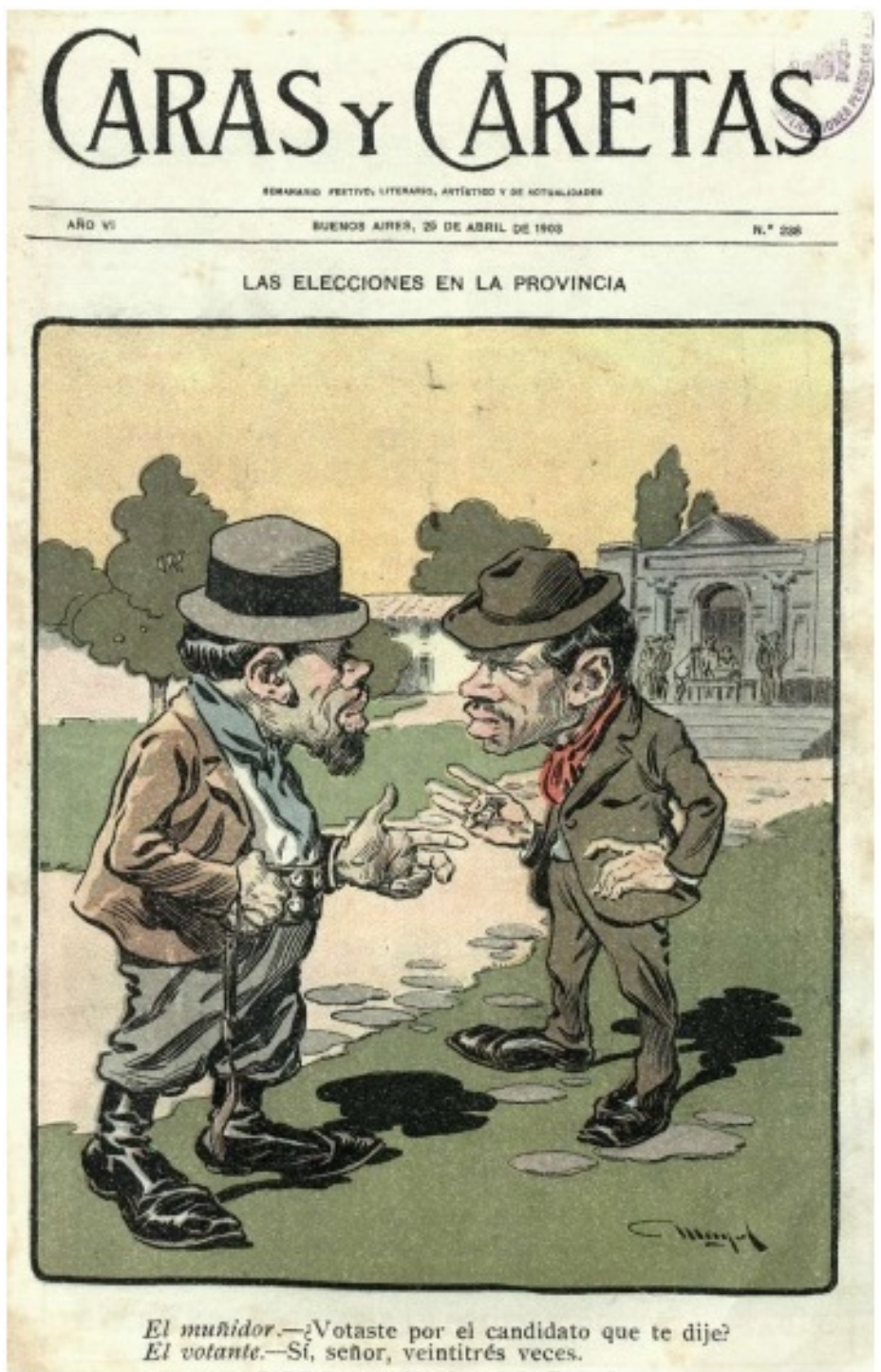

[Caricatura de portada] en semanario Caras y Caretas, 25 de abril de 1903, n. ${ }^{\circ} 238$, Año VI. 
Manuel Mayol, su autor, traza un dibujo que representa, es decir, que vuelve a presentar y en ese procedimiento, construye. Posiciona a los lectores-espectadores en una situación de la cual no eran partícipes hasta que frente a sus ojos tuvieron la caricatura. Mayol, lápiz en mano, instituye. Dado que caricatura del italiano caricare, puede entenderse como "cargar" o "exagerar" (Gombrich, 1998 [1962]) la iconografía de portada redobló esfuerzos sobre lo conocido, de un modo burlón o hasta grotesco.

Podemos interrogarnos si efectivamente los lectores-espectadores de Caras y Caretas conocían las formas aludidas por el dibujante. Aunque nunca hubieran vivenciado una charla de esas características (justamente por lo recargada que la misma aparece en su formato caricaturesco) no les resultaría una realidad lejana. Desde el propio semanario se aportaron referencias sobre comportamientos similares a los construidos en ese mensaje visual (Gómez, 2016a). En una nota publicada con anterioridad a la caricatura, y con motivo de las elecciones efectuadas en General Paz (provincia de Buenos Aires) de 1903, se afirmó por ejemplo: "Se conoce por la actitud de los escrutadores y de los votantes, que allí no había adversarios: el acto era de "puritos ellos no más" como se dice en criollo" ("Las elecciones en General Paz” en Caras y Caretas, 4/04/1903). Posiblemente, estas actuaciones se encontraban naturalizadas por los lectores-espectadores, sea porque las vivenciaban en primera persona o porque se enteraban sobre estos comportamientos mediantes publicaciones como el semanario. Ese conocimiento, entendemos, es el que permite la risa.

La fuerza de la aseveración trasmitida por la imagen, sin embargo, no se halla en la praxis re-presentada sino por el contrario, en la fractura de la privacidad que produce todo aquel que decodifica el mensaje visual. En la construcción del caricaturista, muñidor y elector se disponen distanciados de otras personas que en la imagen aparecen desdibujadas, empequeñecidas y enmarcadas en una construcción distante. Mayol incorpora la perspectiva para acentuar que hay quienes se encontraban en un segundo plano, y por ende, no pueden escuchar la charla sostenida por los hombres de delante. Los lectores-espectadores, sin embargo, se encontraron muy cerca. Esa proximidad permite oír (leer) lo que hablan muñidor y votante. Para ello Mayol insertó un diálogo breve y contundente que orienta el sentido de la caricatura: "El muñidor. -¿Votaste por el candidato que te dije?/El votante. -Sí, señor, veintitrés veces" ("Las elecciones de la provincia" en Caras $y$ Caretas, 25/04/1903).

Mayol entonces posiciona de una manera particular a quienes leen y miran el mensaje visual. Devenidos en cómplices del caricaturista, los lectores-espectadores pueden husmear en una charla ajena. El dibujante parece buscar que quien tuviera en sus manos el ejemplar de la revista, no fuera descubierto por el muñidor y el votante, pero al mismo tiempo, que supiera sobre la situación instituida.

A primera vista, el dibujante descentró a los principales actores. A la izquierda, la distancia entre el cuerpo del muñidor y el margen delineado de la caricatura es menor a la que separa al elector del margen derecho. Quizás entonces la mirada no debe apreciar los cuerpos sino un elemento que apareció en relación a las figuras, esto es, la sombra que ambos proyectan. Si en cambio se percibe la distancia entre margen izquierdo y cuerpo del muñidor, por un lado, y margen derecho y sombra proyectada por el elector, por el otro, encontraremos que Mayol fue muy preciso.

¿Qué importancia tiene este juego de cuerpos y sombras? Una significativa, pues el caricaturista ha insertado un elemento que permite atender al horario. Aunque desconocemos dónde se encontraba el Este en la escena, lo que implicaría mayor exactitud, puede observarse que la longitud de la sombra desplegada por los cuerpos no es demasiado dilatada. De allí que considerando que al mediodía exacto ningún cuerpo produce sombra, sepamos que la hora se aproxima bastante a ese punto del sol: es decir, en la construcción realizada por Mayol, se trata de las 11 o de las $13 \mathrm{~h}$ aproximadamente. 
Como dijimos, el caricaturista separó a muñidor y elector de otras personas -con rostros irreconocibles producto de la distancia- pero permitió apreciar lo que están haciendo: se encuentran en plena jornada electoral, como atestiguan que algunos estén sentados a una mesa donde se halla una urna mientras otros, de pie, están votando. Se ubican en el atrio de una iglesia o de un palacio municipal, en la cima de la escalinata, cuyos rasgos neoclásicos sobresalieron en la escena. Se trata de las típicas construcciones que se desarrollaban en aquellos años en el interior provincial y según disponía la ley electoral provincial n. ${ }^{\circ} 1067$, era el espacio elegido para el desarrollo de las elecciones. ${ }^{8}$ El edificio irrumpe aunque remotamente, como contracara. La presencia de esta arquitectura señaló una edificación "civilizada" (un postulado de civilización que excede la construcción material). Arquitectónicamente, retomaba la tendencia predominante en Europa, en especial, de aquel espacio considerado capital del siglo XIX: una París a la que las clases dirigentes querían imitar. Tras el Plan Haussmann, ese espacio francés se colmó de construcciones neoclásicas -que se reproducían en la Argentina- con frontispicio triangulares e importantes columnas que rememoraban la antigüedad grecoromana. Una fuerte divergencia entre aquello que pudo conmemorar (una democracia ateniense) con la utilización que de las formas democráticas realizaban muñidor y elector puede que fuera impuesta por el caricaturista.

Esa edificación posibilitó, entre otras múltiples, una lectura como metáfora democrática (su forma clásica que contrastaría con la realidad argentina en el cambio de siglo, la "política criolla") y puede que hubiera dado ciertas precisiones. Probablemente la escena construida se produzca a las 11 horas pues esas construcciones se realizaron orientadas a la salida del sol, lo que permitiría marcar dónde se encuentra el Este en la escena. Aunque ello no fuera así, y se hubiera tratado como decíamos antes de pasado el mediodía, Mayol una vez más empuja a observar a los lectores-espectadores: la desconfianza del muñidor que coteja si el elector respondió a su pedido con un margen de tiempo suficiente para actuar en caso de que quien debía votar no lo hubiera hecho de la manera o la cantidad de veces que se le consignó. Una constante en variadas notas periodísticas y relatos publicados en el semanario donde se afirmaba el valor del voto en el mercado electoral, el aumento del precio del sufragio en tanto se aproximaba la hora del cierre de los comicios y la constatación por parte de mediadores de que la elección se torcía a favor de la fuerza política que cada bróker representaba (Gómez, 2016a).

Sin embargo, en la construcción realizada por el caricaturista, la actitud del muñidor no es solo de cautela pues su mera presencia amedrenta. Cierto señalamiento que da fuerza a sus palabras se produce con la mano izquierda mientras con la derecha sostiene un rebenque y se toma del cinto. Toda su ropa, además, presenta otra calidad que la del elector: el sombrero, más alto y formado, el lustre de sus zapatos o el brillo de las prendas del bróker contrastan con el ropaje gastado del elector. Despreocupado, con mano a la cintura, el votante fue construido respetando al muñidor. Se refiere a él como "señor". Un camino de barro se constituyó por las huellas que dejó tras volver de la mesa electoral. La referencia de Mayol a un ambiente poco más que urbanizado (solo la edificación de la iglesia o municipalidad y una construcción que no puede divisarse del todo destacaron en cierta atmósfera rural) posiciona a los lectores-espectadores frente a un típico municipio bonaerense (indicación del espacio dada en el título) donde afloraron prácticas extendidas del siglo XIX en los inicios del siglo XX. Esa es la realidad que Mayol construye, aquella que en un juego especular entre espacio nacional y bonaerense, pretendió remarcar cómo se vivenciaban las elecciones. Mayol hace parte a los lectoresespectadores del semanario de una situación conocida pero exagerada, poniendo de relieve en la portada del semanario, mecanismos fraudulentos en un país que meses antes había discutido su normativa electoral e intentó (aunque sin éxito) acabar con el voto venal mediante la ley uninominal por circunscripciones de 1902 (Gómez, 2013).

\section{II. b.}

A mediados de 1916, los habitantes de una ciudad bonaerense se pasean luciendo una boina blanca. Publicada por el semanario el 1 de julio de 1916, la caricatura apareció en tapa sin firma y titulada como "La última moda”. (Véase Figura 7). 


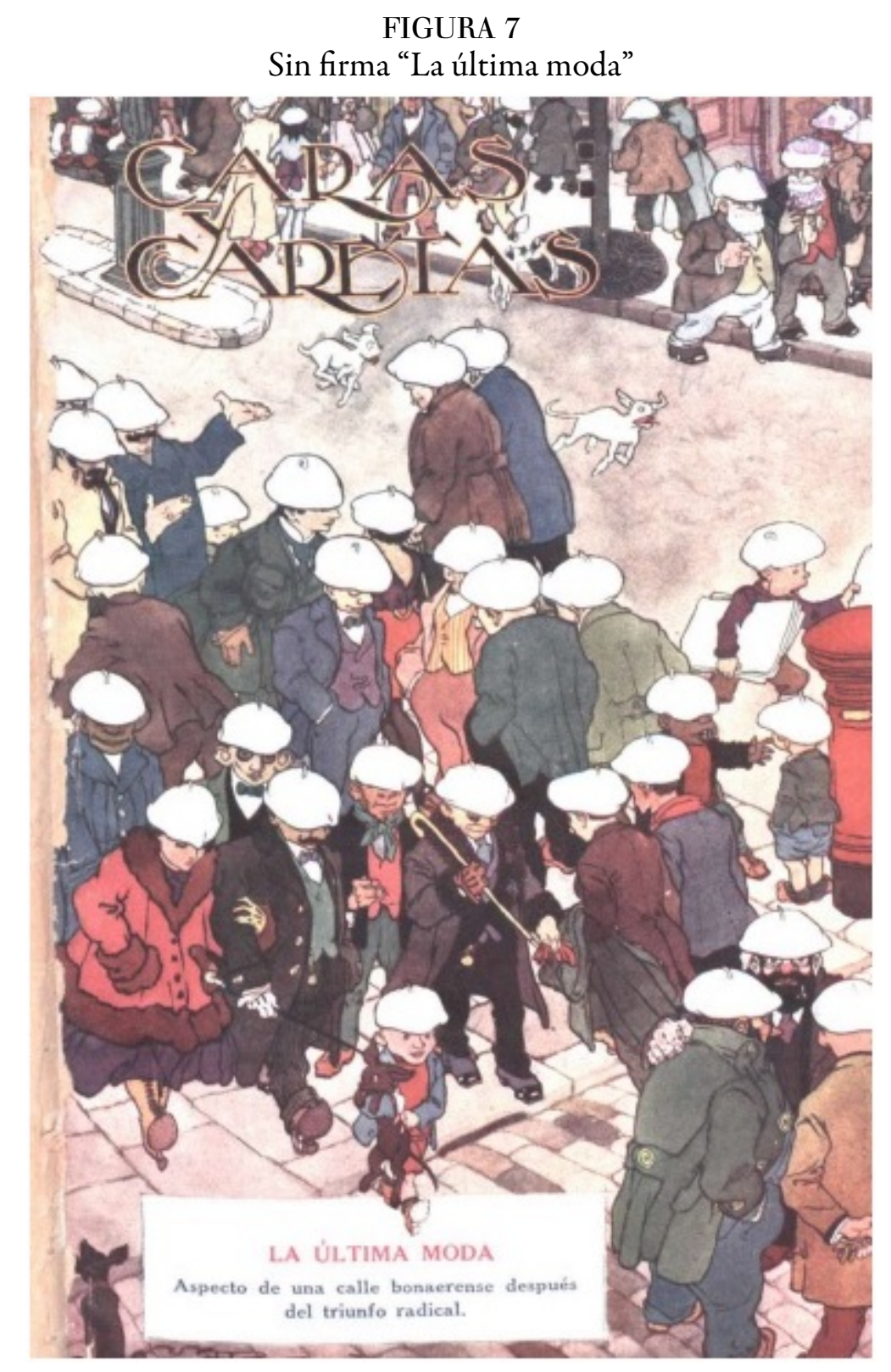

[Caricatura de portada] en semanario Caras y Caretas, 1 de julio de 1916, n. 926, Año XIX.

La estrofa que orienta el sentido de la gráfica afirma: "Aspecto de una calle bonaerense después del triunfo radical" ("La última moda" en Caras y Caretas, 1/07/1916). Los lectores-espectadores no cuentan con precisiones sobre la ubicación de la escena pues ningún rasgo específico permite con certeza asegurar a qué ciudad se alude. En el número donde la caricatura fue publicada, no hay referencias a otras imágenes que permitan emparentar la escena a una situación, por ejemplo, fotografiada. ${ }^{9}$ Como en la caricatura anterior entonces, solamente sabemos que se trata de algún municipio bonaerense.

En la escena construida por el caricaturista, dos niños son retratados vendiendo periódicos (uno en el sector derecho de la imagen mientras que el otro se visibiliza arriba a la izquierda sosteniendo un diario en mano en señal de oferta). Sin embargo, esas publicaciones se presentaron completamente en blanco, cualidad que destaca en lo nutrido de la escena.

Alrededor de 45 personas fueron presentadas en la caricatura. La precisión en el dibujo permite conocer que hablan pero, a diferencia de la caricatura de Mayol, no es posible para los lectores-espectadores acceder a esas conversaciones. ¿Dónde entonces se posaría la mirada? 
Es probable que, en primer lugar, en la cantidad de gente. A diferencia del mensaje visual de 1903 donde los protagonistas principales fueron dos (muñidor y elector) aquí se construye una situación plagada de actores. La democratización es retratada (y exagerada) con ímpetu. Aunque no se hace hincapié en un momento electoral sino en uno posterior a las urnas, los lectores-espectadores son interpelados una vez más sobre comportamientos de personas corrientes vivenciando la política.

El caricaturista incorpora además de hombres, a mujeres y niños, estos últimos, sujetos que no pueden votar. Como indicio, ello permite reflexionar en torno a procesos de producción de sentido entendidos como semiosis social (Verón, 1993 [1987]). Pues no se trata de visualizar quiénes votan (los electores) sino la fidelidad que las personas detentan (sea porque efectivamente pudieran participar de procesos electorales y hubieran votado por el radicalismo, no lo hubieran hecho por ese partido o siquiera concurrieran a las urnas). "La última moda" construye una situación particular. En una provincia gobernada en aquella época por Marcelino Ugarte, arquetipo de caudillo conservador (Debenedetti, 2005), el caricaturista instituye muestras de fidelidad al radicalismo (expresada en la boina blanca) con la que variadas personas intentarían conseguir algún favor (aun cuando no participaran de los comicios).

La consideración de posibles estrategias que los habitantes del llano desarrollaban no era novedosa en el semanario. Distintas notas y relatos ficcionales dieron cuenta de estratagemas, astucias y artificios desde finales del siglo XIX. Hacia 1900, la revista acentuaba el mercadeo del voto, el valor monetario que el sufragio adquiría y los esfuerzos que suponían estos procedimientos por parte de quienes intentaron formar parte del grupo dirigente. Tras la llegada al poder nacional por parte del radicalismo, la imagen proyectada desde el semanario vinculó los comportamientos de los electores (que crecían en número tras las novedades normativas) ya no a la comercialización del sufragio sino a la estrategia implementada por el radicalismo desde 1916 (Gómez, 2016), la "empleomanía” (Persello, 2000). Tampoco era nueva la idea de "moda" que se impuso en este mensaje visual, pues ya en 1912 se había expresado que "la nueva ley electoral, ha tenido la virtud de imponerse como las modas" ("La política de ahora” en Caras y Caretas, 19/10/1912) en una nota donde se remarcaban las limitaciones de la normativa respecto a las modificaciones acarreadas en las prácticas políticas.

Lo que se presenta en este contexto como novedoso es la mixtura de palabras e imágenes realizada en general por el semanario. No solo cuando se trató de estos mensajes visuales (cuya creación corría exclusivamente a cargo de los dibujantes del semanario) sino en otro tipo de combinación. La fotografía ya referenciada del cartel colocado en el Club Carlos Pellegrini (Véase Figura 4) fue publicada con un sugerente epígrafe: "Una broma pesada-Cayetano Ganghi no compraba votos" ("La reclame electoral" en Caras y Caretas, 13/04/1912). Es decir, hubo una utilización de elementos textuales e imágenes en mensajes que sistemáticamente fueron transmitidos desde la revista y que, en función de la fuerza de las aseveraciones planteadas, se nos presentan como indicios de la percepción de la realidad política que el semanario difundía y por medio de la cual, eventualmente, podría influir o aportar a los modos en que los lectores-espectadores del semanario comprenderían la vida política epocal. Ello no debe interpretarse como una supuesta influencia lineal y directa sobre la opinión pública, pues desde las mismas páginas de Caras y Caretas se advirtió sobre las construcciones realizadas por las publicaciones: "Si uno lee los diarios, todos los candidatos son peores" ("Lo de siempre” en Caras y Caretas, 22/04/1916). Empero, diferenciándose de la iconografía política (o de lo que el semanario entendió por tal), que en la mirada de la revista buscaba aproximarse a un número amplio de personas utilizando primero textos y posteriormente palabras e imágenes para "acercar" candidatos a potenciales votantes, en la transición de una política de notables a una de masas, el semanario apeló a lectoresespectadores que se convertían en electores. Estos no solo constituían la amplia mayoría de su público sino que, al mismo tiempo, fueron los principales protagonistas en las construcciones realizadas por el semanario. La ubicación en el centro de la escena de los lectores-espectadores y el conocimiento mutuo sobre algunos modos de la política criolla, generó una complicidad entre el público y la revista, donde "la política" era puesta 
en entredicho. Entre risas entonces, se conformaban también desde las páginas de Caras y Caretas, imágenes de "lo político".

\section{IMÁGENES Y POLÍTICA: LA CAPACIDAD DE INSTITUIR.}

A lo largo de este artículo, examinamos a Caras y Caretas partiendo de considerarla una revista de bajo costo y gran circulación que volvió masivos mensajes que combinaban (merced a los adelantos técnicos) imágenes y palabras para un número cada vez mayor de personas, en tanto la población seguía creciendo en nuestro país y el analfabetismo se reducía.

Indagamos desde el lanzamiento del semanario en 1898 hasta 1916, año en el que según la revista la iconografía política había alcanzado gran desarrollo y jugaba un rol importante.

Para Caras y Caretas, durante los primeros años del siglo XX y en línea con lo que sucedía a finales del XIX, la actividad proselitista se valió de carteles, afiches y pancartas que apelaron casi exclusivamente a los textos. Hacia la segunda década del siglo XX, esos mensajes se complejizaron al incluir combinaciones de palabras e imágenes. En un contexto de ampliación del juego político, la revista señaló que las distintas fuerzas apelaron a lectores-espectadores en tanto potenciales electores, por medio de mensajes que combinaban texto y elementos icónicos. En esa dirección, el semanario se valió de caricaturas y la publicación de fotografías para resaltar la incorporación de gráfica junto a las habituales palabras que habían primado en los cartelones partidarios.

Para conocer el desarrollo de esta iconografía y distinguir, por ejemplo, su impulso en grandes urbes o ciudades pequeñas, se requeriría de un estudio que apele a otras fuentes ya que en el semanario contamos con escasas o nulas especificaciones que den cuenta de los lugares aludidos (dónde fueron tomadas las fotografías o a qué espacio parodiaba una caricatura). Sin embargo, nuestro objetivo fue otro: no tratamos de cotejar cuán representativo era lo expresado por la revista con la realidad (que a priori podemos pensar como múltiple y diversa considerando lo heterogéneo del territorio argentino), sino que buscamos hacer hincapié en los modos con los que la revista remarcó lo que consideró una extensión y desarrollo de una cada vez más elaborada iconografía política.

Caras y Caretas entonces como revista que masifica la combinación de imágenes y palabras realizó un examen de esa combinación en la actividad proselitista por medio de imágenes y palabras. Aunque no solamente eso. En sus caricaturas de portada exageró, cargó y potenció algunos rasgos en desmedro de otros de la que en la época era conocida como politica criolla. Las tapas del semanario contuvieron mensajes visuales que apelaron al fraude, el voto venal, el accionar de mediadores y las estrategias de diversos actores en la transición de una política de notables a una que se democratizaba (aunque con restricciones fundamentalmente de género y étnicas). Situando las construcciones en la provincia de Buenos Aires como modo de desandar la política nacional (en un procedimiento implementado también por otras publicaciones muy distintas al semanario como la Revista Argentina de Ciencias Politicas) Caras y Caretas promovió imágenes socialmente imaginadas y compartidas con los lectores-espectadores acerca del savoir faire político epocal. Un análisis indiciario de dos mensajes visuales de portada como el que emprendimos revela, entre otros aspectos, que la interpelación a esos lectores-espectadores se produjo principalmente en ese conocimiento compartido y en la ubicación como principales protagonistas de esas caricaturas. En otras palabras: los mensajes visuales de tapa aluden a personas del llano vivenciando la política, anónimos que no se correspondían con alguien en específico pero que al mismo tiempo podía ser cualquiera de los lectoresespectadores.

Al considerar, poner en valor y remarcar el desarrollo de la iconografía política por parte de distintas fuerzas así como recargar situaciones donde personas corrientes vivenciaban prácticas políticas, Caras y Caretas instituyó imágenes de lo político. 


\section{Bibliografía.}

Alonso, P. (2000). Entre la revolución y las urnas. Los origenes de la Unión Cívica Radical y la politica argentina en los años noventa. Buenos Aires: Sudamericana.

Ansaldi, W. (1999). Crear al sufragante. La universalización masculina de la ciudadanía política en Argentina. La reforma electoral de 1912. Annales, 2, 155-200.

Ansaldi, W. (2000). La trunca transición del régimen político oligárquico al régimen democrático. En R. Falcón (Dir.), Nueva Historia Argentina. Tomo V: Democracia, conflicto social y renovación de ideas, 1916-1930 (pp. 15-57). Buenos Aires: Sudamericana.

Ansaldi, W. (2012). Que nos voten antes que nos boten: la reforma electoral de 1912. Estudios Sociales, 1(43), 59-90.

Ansaldi, W., Pucciarelli, A. y Villarruel, J. (Ed.) (1995). Representaciones inconclusas. Las clases, los actores y los discursos de la memoria, 1912-1946. Buenos Aires: Biblos.

Ariés, P. (1980). Un historien de dimanche. París: Seuil.

Auza, N. (2008). Revista Argentina de Ciencias Politicas. Estudio e Índice General, 1910-1920. Homenaje a su fundador Dr. Rodolfo Rivarola en su sesquicentenario. Buenos Aires: Academia Nacional de Ciencias Morales y Políticas.

Barba, F. (2004). Los tiempos perdidos. La politica de Buenos Aires entre 1880 y la intervención federal de 1917. Buenos Aires: Archivo Histórico de la Provincia de Buenos Aires Dr. Ricardo Levene.

Barthes, R. (2001 [1993]). La Torre Eiffel. Textos sobre la imagen. Buenos Aires: Paidós.

Béjar. M. (2005). El régimen fraudulento. La politica en la provincia de Buenos Aires, 1930-1943. Buenos Aires: Siglo XXI Editores.

Bonaudo M. y Mauro, D. (2014). Las paradojas del reformismo liberal. De la experiencia de la liga a la construcción del partido (1897-1931). Estudios Sociales ,46, 119-144.

Bonaudo, M. (2005). De la opinión publicada a la opinión pública. La prensa como lugar de representación y de conflicto. En M. Bonaudo, Imaginarios y prácticas de un orden burgués. Rosario, 1850-1930 (pp. 71-94). Rosario: Prohistoria ediciones.

Bonaudo, M. (2015). Repensando el partido/facción en la experiencia latinoamericana. Illes Imperis, 17, 15-42.

Botana, N. (2012 [1977]). El orden conservador. La politica argentina entre 1880 y 1916. Buenos Aires: Edhasa.

Botana, N. y Gallo, E. (1997). De la República Posible a la República Verdadera (1880-1910). Buenos Aires: Emecé Editores.

Burke, P. (2005 [2001]).Visto y no visto. El uso de la imagen como documento histórico. Barcelona: Crítica

Burucúa, J. E. (2006). Historia y ambivalencia. Ensayos sobre arte. Buenos Aires: Biblos.

Caimari, L (2015). El mundo al instante. Noticias y temporalidades en la era del cable submarino (1860-1900). Redes, 21(40), 125-146. Recuperado de http://www.unq.edu.ar/advf/documentos/58b070f4be129.pdf

Cárdenes, A. (2014). Mario A. Rivarola y la Revista Argentina de Ciencias Políticas: el sistema político argentino puesto bajo la lupa. En T. Ortiz (coord.), Nuevos aportes a la historia de la Facultad de Derecho de la Universidad Nacional de Buenos Aires, (pp. 143-176). Buenos Aires: Depto. de Publicaciones de la Facultad de Derecho de la UBA.

Cardona Laites, A. (2015). El fenómeno editorial Caras y Caretas y el papel del escritor en sus páginas: Horacio Quiroga y S. Fragoso Lima. Questión. Revista especializada en periodismo y comunicación, 1(48), 78-92.

Castro, M. (2012). El ocaso de la República Oligárquica. Poder, política y reforma electoral 1898-1912. Buenos Aires: Edhasa.

Chartier, R. (2008). Aprender a leer, leer para aprender. En Millán, J. La lectura en España. Informe 2008, (pp. 23-39). Madrid: Federación de Gremios Editores de España.

Clerici, E. (2016). El lujo de pertenecer: imágenes en los carteles artísticos porteños (1898-1920). En S. Szir (coord.), Ilustrar e imprimir. Una historia de la cultura gráfica en Buenos Aires, 1830-1930, (pp. 213-236). Buenos Aires: Ampersand. 
Cuarterolo, A. (2017). Entre caras y caretas: caricatura y fotografía en los inicios de la prensa ilustrada argentina. Signifição, 44(47), 155-177.

de Privitellio, L. (2006). Representación política, orden y progreso. La reforma electoral de 1902. Política y Gestión, 9, 109-134.

de Privitellio, L. (2009). El imperio de la voluntad popular: el "fraude" y el estudio de las elecciones en la primera mitad del siglo XX. La Fundación Cultural, 38, 57-70.

Debenedetti, E. (2005). Marcelino Ugarte. Arquetipo de caudillo conservador. La Plata: Instituto Cultural de la Provincia de Buenos Aires/Publicaciones del Archivo Histórico de la Provincia de Buenos Aires Dr. Ricardo Levene.

Devoto, F. y Ferrari, M. (comps.) (1994). La construcción de las democracias rioplatenses: proyectos institucionales y prácticas políticas, 1900-1930. Buenos Aires: Biblos.

Eujanián, A. (1999). Historia de revistas argentinas. 1900-1950. La conquista del público. Buenos Aires: AAER.

Fara, C. (2012). Una ciudad de papel. Imágenes de Buenos Aires en Caras y Caretas 1920-1939. Avances. Revista del área de Artes, Universidad Nacional de Córdoba, 12(19), 97-109.

Fernández, S. (2010). La revista El Círculo o el arte de papel. Una experiencia editorial en la Argentina del Centenario. Murcia: Universidad de Murcia.

Fernández, S. y Navarro, F. (2011). Scribere est agere. Estanislao Zeballos en la vorágine de la modernidad argentina. Rosario: Quinta Pata \& Camino Ediciones.

Ferrari, M. (2008). Los políticos en la república radical. Prácticas políticas y construcción del poder (1916-1930). Buenos Aires: Siglo Veintiuno Editores.

Ferrari, M. (2009). Resultados electorales y sistema politico en la Provincia de Buenos Aires (1913-1934). La Plata: Instituto Cultural de la Provincia de Buenos Aires / Archivo Histórico Dr. Ricardo Levene.

Ferraro, L. (2003). Una aproximación al reformismo político de Rodolfo Rivarola. Prácticas, partidos y representación política en un espacio de opinión: «La Revista Argentina de Ciencias Políticas» 1914-1916. Revista de Historia Americana y Argentina, Mendoza, 40, 137-154.

Fritzsche, P. (2008). Berlin 1900. Prensa, lectores y vida moderna. Buenos Aires: Siglo XXI Editores.

Gallo, E. y Cortés Conde, R. (2005 [1995]). Historia Argentina 5: La república conservadora. Buenos Aires: Paidós.

Gamarnik, C. (2018). La fotografía en Caras y Caretas en Argentina (1898-1939): innovaciones técnicas, profesionalización e imágenes de actualidad. Estudos Iberoamericanos, Porto Alegre, 44(1), 120-137.

Gantús, F. (2007). Porfirio Díaz y los símbolos de poder. La caricatura política en la construcción de imaginarios. Cuicuilco, 40(14), 205-225.

Gantús, F. (2009). Caricatura y poder politico: critica, censura y represión en la Ciudad de México, 1876-1888. México: El Colegio de México.

Ginzburg, C. (1984 [1981]). Ensayo sobre Piero. Barcelona: Muchnik.

Ginzburg, C. (2014). Medo, reverencia, terror. Quatro ensaios de iconografía politica. Lisboa: Companhia das Letras.

Girbal-Blacha, N. y Quattrochi-Wilson, D. (1999). Cuando opinar es actuar. Revistas argentinas del siglo XX. Buenos Aires: Academia Nacional de la Historia.

Gombrich, E. (1998) [1962]. Meditaciones sobre un caballo de juguete. Yotros ensayos sobre la teoría del arte. España: Debate.

Gómez, S. (2013). Pa' eso soy un ciudadano consciente: Caras y Caretas y la reforma electoral de 1902. Cambios y Permanencias, 4(4), 172-200. Recuperado de https://revistas.uis.edu.co/index.php/revistacyp/article/view/73 $23 / 7577$

Gómez, S. (2015). Caras y Caretas. El semanario como caricatura. Estudios del ISHIR, 5(5), 154-176. Recuperado de http://revista.ishir-conicet.gov.ar/ojs/index.php/revistaISHIR/article/view/545

Gómez, S. (2016a). Clientelismo y poder politico en los inicios del siglo XX. Tensiones, disputas e intercambios entre lo micro y lo macro: Benito Juárez y la provincia de Buenos Aires (Tesis doctoral inédita). Universidad Nacional de 
La Plata. Facultad de Humanidades y Ciencias de la Educación. La Plata, Argentina. Doctorado de Historia, Universidad Nacional de la Plata.

Gómez, S. (2016b). Tinta y política en una pequeña comunidad bonaerense: Benito Juárez, 1902-1930. Historia Regional, 34, 35-45.

Gómez, S. (2017). Ciudadanos conscientes e inconscientes: la política argentina contemplada y construida por Caras y Caretas, 1898-1916. Actas del Congreso AHILA 2017 (pp. 141-164). Valencia: Universitat de Valencia.

Gubern, R. (1996). Del bisonte a la realidad virtual. La escena y el laberinto. Barcelona: Anagrama.

Horowitz, J. (2014). El radicalismo y el movimiento popular (1916-1930). Buenos Aires: Edhasa.

Karush, M. (1999). Workers, Citizens and the Argentine Nation: Party politics and the working class in Rosario, 1912-3. Journal of Latin American Studies, 31(3), 589-616.

Rivarola, R. (1917). La intervención a Buenos Aires. Revista Argentina de Ciencias Políticas, 80 (7), 117-127.

Leiras, M., Abal Medina, J. y D'Alessandro, M. (2005). La ciencia política en Argentina: el camino de la institucionalización dentro y fuera de las aulas universitarias. Revista de Ciencia Política, 25(1), 76-91.

Ludmer, J. (1999). El cuerpo del delito. Un Manual. Buenos Aires: Perfil.

Man, R. (2011). Rosario en el Centenario. Movilizaciones sociales, conflictividad, ciudadanía politica y opinión pública en torno a 1910. Rosario: Quinta Para \& Camino Ediciones.

Mauro, D., Cesaretti, F y Uliana, H. (2005). Del resplandor a la opacidad. Opinión pública, empresas periodísticas y ciudadanía. La "nueva prensa" de Rosario en la década del 20: los casos de Reacción y Reflejos. En Bonaudo, M., Imaginarios y prácticas de un orden burgués. Rosario, 1850-1930 (pp. 97-123). Rosario: Prohistoria ediciones.

Melón, J. (1994). La Ley Sáenz Peña de Ugarte o el éxito de la reforma conservadora en la provincia de Buenos Aires. En Devoto, F. y Ferrari, M., La construcción de las democracias rioplatenses: proyectos institucionales y prácticas políticas, 1900-1930 (pp. 107-135). Buenos Aires: Biblos.

Míguez, E. (2003). El sistema político argentino en la década de 1890. Desarrollo Económico, 42(168), 667-671.

Miguez, E. (2012). Gestación, auge y crisis del orden político oligárquico en la Argentina. Balance de la historiografía reciente. Revista Polhis, 5(9), 38-68.

Moraña, A. (2008). La propaganda, la moda y el consumo en la revista Caras y Caretas (Argentina, 1898-1910). Estudios, 16(32), 249-273.

Mustapic, A. (1987). El Partido conservador de la provincia de Buenos Aires ante la Intervención federal y la competencia democrática, 1917-1928. Documento de Trabajo N. ${ }^{\circ} 95$. Buenos Aires: Instituto Torcuato Di Tella.

Paredes, R. (1996). Modernización y clientelismo conservador. Radicales, socialistas y populares en Campana (1910-1930). En J. Meló y E. Pastoriza (Ed.), Los caminos de la democracia. Alternativas y prácticas políticas, 1900-1943 (pp. 201-214). Buenos Aires: Biblos.

Pastormerlo, S. (2014 [2006]). 1880-1889. El surgimiento de un mercado editorial. En de J. Diego (Dir.), Editores y politicas editoriales en Argentina (1880-1910) (pp. 1-29). Buenos Aires: Fondo de Cultura Económica.

Pereyra, H. (1958). La reforma a la ley electoral de 1902. Proyecto de Joaquín V. González. Trabajo y Comunicaciones, 7. Disponible en Sociohistórica, 6. Recuperado de http://www.memoria.fahce.unlp.edu.ar/art_revistas/pr.2807 /pr.2807.pdf

Pérez Vejo, T. (2005). Nacionalismo e imperialismo en el siglo XIX: dos ejemplos de uso de las imágenes como herramienta de análisis histórico. En F. Aguayo y L. Roca, Imágenes e Investigación Social (pp. 48-75). México: Instituto de Investigaciones Dr. José María Luis Mora.

Persello, A. (2000). Administración y política en los gobiernos radicales, 1916-1930. Sociohistórica, 8, 121-152. Recuperado de https://www.sociohistorica.fahce.unlp.edu.ar/article/view/SHn08a04

Persello, V. y de Privitellio, L. (2009). La Reforma y las reformas: la cuestión electoral en el Congreso (1912-1930). En L. Bertoni y L. de Privitellio (comp), Conflictos en democracia. La vida politica argentina entre dos siglos (pp. 89-121). Buenos Aires: Siglo Veintiuno Editores.

Prieto, A. (2006 [1988]). El discurso criollista en la formación de la Argentina moderna. Buenos Aires: Sudamericana. Rivera, J. (1985). El escritor y la industria cultural (pp. 313-336). Buenos Aires: Atuel. 
Rock, D. (1997 [1977]). El radicalismo argentino. 1890-1930. Buenos Aires: Amorrortu Ediciones.

Rogers, G. (2008). Caras y Caretas: cultura, política y espectáculo en los inicios del siglo XX argentino. La Plata: Editorial de la Universidad Nacional de La Plata.

Rojas Mix, M. (2006). El imaginario. Civilización y cultura del siglo XXI. Buenos Aires: Prometeo Libros.

Rojas, R. (1948). Historia de la Literatura Argentina. Los modernos. Buenos Aires: Losada.

Roldán, D. (comp.). (2006). Crear la democracia. La Revista Argentina de Ciencias Políticas y el debate en torno a la República Verdadera. Buenos Aires: Fondo de Cultura Económica.

Román, C. (2010a). La modernización de la prensa periódica, entre La Patria Argentina (1879) y Caras y Caretas (1898). En A Laera (Dir.), Historia crítica de la literatura argentina. Volumen 3: El brote de los géneros (pp. 15-38). Buenos Aires: Emecé

Román, C. (2010 b). La prensa satírica argentina del siglo XIX:palabras e imágenes (Tesis de Doctorado). Universidad Nacional de Buenos Aires, Facultad de Filosofía y Letras, Buenos Aires, Argentina.

Román, C. (2016). Prensa, politica y cultura visual. El Mosquito (Buenos Aires, 1863-1893). Buenos Aires: Amperstand. Rosanvallon, P. (2006 [2003]). Por una historia conceptual de lo político. Madrid: Fondo de Cultura Económica de España.

Saítta, S. (1998). Regueros de tinta. El diario Crítica en la década de 1920. Buenos Aires: Sudamericana.

Sarlo, B. (1985). El imperio de los sentimientos. Narraciones de circulación periódica en la Argentina (1917-1927). Buenos Aires: Catálogos Editora.

Servelli, M. (2014). A través de la República. La emergencia del reporterismo viajero en la prensa porteña de entresiglos $(X I X-X X)$ (Tesis doctoral inédita). Universidad Nacional de Buenos Aires, Facultad de Filosofía y Letras, Buenos Aires, Argentina.

Sidicaro, R. (1993). La politica mirada desde arriba. Buenos Aires: Sudamericana.

Szir, S. (Coord.) (2016). Ilustrar e imprimir. Una historia de la cultura gráfica en Buenos Aires, 1830-1930. Buenos Aires: Amperstand.

Tato, M. (2009). Nacionalistas y conservadores, entre Yrigoyen y la década infame.En L. Bertoni y de L. Privitiello, Conflictos en democracia. La vida politica argentina entre dos siglos. Buenos Aires: Siglo XXI.

Taub, E. (2008). Otredad, orientalismo e identidad: nociones sobre la construcción de otro oriental en la revista Caras y Caretas: 1898-1918. Buenos Aires: Editorial Teseo.

Tell, V. (2017). El lado invisible. Fotografía y progreso en la Argentina a fines del siglo XIX. Buenos Aires: UNSAM.

Verón, E. (1993 [1987]). La semiosis social. Fragmentos de una teoria de la discursividad. Barcelona: Gedisa.

Vovelle, M. (1979). Iconographie et histoire des mentalités. Paris: Centre National de la recherche scientifique

Walter, R. (1987). La provincia de Buenos Aires en la politica argentina. 1912-1943. Buenos Aires: Emecé.

Zimmermann, E. (1995). Los liberales reformistas. La cuestión social en la Argentina, 1880-1916. Buenos Aires: Sudamericana-Universidad de San Andrés.

\section{Notas}

1 Hacia 1869, la población en Argentina alcanzaba 1.737.076 personas. En 1895, fueron censados 3.954.911 habitantes. En 1914, se identificaron 7.885.237. Véanse Censos Nacionales de 1869, 1895 y 1914.

2 La instrucción pública en Argentina fue en aumento desde la segunda mitad del siglo XIX. Un mayor número de "escolares" (niños entre 6 y 14 años según ley de censo del 6 de junio de 1883) se sumaba a las aulas. En 1869, alrededor de 82000 concurrían a la escuela, un $20 \%$ de quienes habitaban en el territorio en esa franja etaria, 409876. El Censo Escolar de 1883 mostró 145000 inscriptos y el Nacional de 1895 alrededor de 247000. Sin embargo, las cifras deben cotejarse con la cantidad de disertantes (entre el 90 y $97 \%$ ) la mayor parte, entre el primer y segundo año de instrucción (Prieto, 2006 [1988]). En el cambio de siglo, encontramos una mayor presencia de niños y jóvenes en las escuelas: según el Censo Nacional de 1914, 878.237. La provincia de Buenos Aires tenía un porcentaje importante dentro del total: 2.095 escuelas repartidas en el espacio bonaerense, con 6.392 maestros que instruían a 203.756, cifra esta última cercana 
a quienes se educaban en Capital Federal (190.317) pero muy superior a lo que sucedía en otros espacios provinciales (Santa Fe, 75.779 y Córdoba, 87.127). Véase Censo Escolar de 1883 y Censos Nacionales de 1869, 1889 y 1914.

3 El promedio se realizó atendiendo a las cifras referidas en el conocido como Informe Bialet Massé (Bialet Massé, 1904).

4 No nos detenemos aquí en los variados debates que surgen de esas denominaciones y las implicaciones para entender los modos de practicar la política por aquellos años. Al respecto, puede consultarse entre otros: Alonso (2000); Míguez (2003); Persello y de Privitellio (2009) y Bonaudo (2015).

5 Hacemos referencia a los carteles implementados en la actividad proselitista. Acerca de la presencia de variados carteles y el placer visual en las ciudades, pueden consultarse Fritzsche (2008). Para el caso argentino, y en relación a los carteles artísticos porteños entre finales del siglo XIX y comienzos del XX, Clerici (2016).

6 La progresión se realizó en base a cuatro caricaturas de portada. A saber de izquierda a derecha: Mayol, "Pidiendo gollerías" (Caricatura de portada) en semanario Caras y Caretas, 2 de noviembre de 1901, n. ${ }^{\circ}$ 161, año IV; Mayol "Elecciones de verdad" (Caricatura de portada) en semanario Caras y Caretas, 7 de noviembre de 1903, n. ${ }^{\circ}$ 266, Año IV; Mayol "Electores conscientes" en semanario Caras y Caretas, 23 de abril de 1904, n. ${ }^{\circ} 290$, año VIII y Sin firma en portada “Adelante los que quedan" (Caricatura de tapa) en semanario Caras y Caretas, 21 de octubre de 1919, n. ${ }^{\circ}$ 942, Año XIX.

7 Algunos ejemplos son: Mayol, "El campeón electoral” en Caras y Caretas (09/12/1899); Mayol, "Elecciones de Verdad" en Caras y Caretas (07/11/1903); Mayol, “Aparato Inservible” en Caras y Caretas (06/12/1913); Alonso, "La falta de carbón” en Caras y Caretas (11/03/1916).

8 La ley electoral n. 1067 aprobada en 1876 establecía que los comicios debían instalarse en el atrio de la iglesia parroquial, y donde no la hubiere, en la Casa Municipal, y en su defecto, el Juzgado de Paz respectivo. Véase Ley n. ${ }^{\circ} 1067$, Provincia de Buenos Aires (1876).

9 Hacemos esta salvedad pues dentro de los recursos implementados por diversos caricaturistas en Caras y Caretas, se encuentra aquel por el cual la caricatura de portada re-presentaba una situación que había sido también re-presentada por una fotografía. Al respecto, puede verse la caricatura de Sáenz Peña saliendo de votar que exacerba rasgos que se presentaron en una fotografía tomada al presidente al momento de las elecciones de 1912. Véase Cao "El voto del presidente" en Caras y Caretas, 13/04/1912 y dentro del mismo número, fotografía aludida. 